Article

\title{
Evaluating the Intra-Industry Comparability of Sustainability Reports: The Case of the Oil and Gas Industry
}

\author{
Andrea Cardoni *, Evgeniia Kiseleva and Simone Terzani \\ Department of Economics, University of Perugia, Via Alessandro Pascoli, 20, 06123 Perugia PG, Italy; \\ evgeniia.kiseleva@studenti.unipg.it (E.K.); simone.terzani@unipg.it (S.T.) \\ * Correspondence: andrea.cardoni@unipg.it; Tel.: +39-75-585-52-53
}

Received: 30 December 2018; Accepted: 16 February 2019; Published: 19 February 2019

check for updates

\begin{abstract}
Environmental, social, and governance (ESG) data are in high demand in financial markets. However, the ESG data provided by companies do not allow for use in the investment decision-making process. The main limiting point for this is a lack of comparability across companies. This paper analyzes the problem of comparability with the aim to evaluate the intra-industry comparability of sustainability reports, framing the analysis on Global Reporting Initiative (GRI) Standards and discussing the results with the support of legitimacy and stakeholder theories. Drawing upon stakeholder and legitimacy theories, as well as financial and sustainability accounting concepts, we propose a theoretical framework of comparability and a methodology to evaluate the level of comparability on a sector-specific basis. The methodological approach adopted in this study is broadly qualitative, with the use of a multiple-stages model. Based on the example of one industry, we discovered that, despite comparability being mostly relevant to the listed companies from the oil and gas sector, the sustainability reports of these companies are still not comparable. Our findings reveal that, despite the availability of a large amount of ESG data and the existence of sustainability frameworks, the problem of comparability is still relevant even for companies that are theoretically most inclined to be comparable.
\end{abstract}

Keywords: sustainability reports; ESG information; GRI framework; comparability; oil and gas

\section{Introduction}

Over the last decade, sustainable investment, also known as environmental, social, and governance (ESG) investing, has been at the center of debate in the accounting and financial literature [1].

Several studies show that ESG investing influences a company's financial results [2,3] and stock value [4]. In 2015, Deutsche Asset \& Wealth Management and Hamburg University published a research study on the correlation between ESG investing and financial performance [2]. The authors analyzed over 2200 papers written on the topic. They found that $47.9 \%$ of the papers showed a positive correlation between ESG investing and financial performance and that $6.9 \%$ showed a negative correlation, while the remaining papers did not identify any correlation.

Previously, Margolis, Elfenbein, and Walsh (2007) researched 167 analytical papers written on the topic [5]. Their findings showed that $67 \%$ of the papers did not show any significant relationship between ESG investing and company performance, 31\% showed a positive relationship, and very few, only $2 \%$, pointed to a negative relationship.

Regardless of these ambiguous theoretical results, more and more investors prefer to undertake sustainable investments with the aim of gaining more long-term benefits [6,7]. The amount of assets under the management of responsible investors increased almost seven times from 2007 to 2017 [6]. 
As this form of investment is becoming more popular, companies are increasingly required to disclose ESG information.

Despite the growing demand for ESG information, there are issues that limit the use of ESG data in the investment practice. From the practitioner's point of view, one of the main factors that limits the use of ESG information is the lack of comparability across companies [8]. This lack of comparability means an inability to use ESG data in the decision-making process for $45-50 \%$ of investors [9]. Academic studies also support these results, claiming that the largest challenge for investors in integrating ESG information in their investment process is the lack of cross-company comparability [10].

To solve the comparability problem, many sustainability reporting frameworks have appeared, such as state and stock exchange guidelines as well as international sustainability reporting standards and frameworks. For example, EU Directive 2014/95/EU lays down the rules on the disclosure of nonfinancial and diversity information by large companies in the European Union. It prescribes the disclosure of the companies' policies regarding particular sustainability topics [11]. The regulation was driven by the aim to harmonize nonfinancial reporting across member states. Moreover, 39 stock exchanges around the world provide nonfinancial reporting guidance [12]. These documents are supposed to help issuers navigate how to report on ESG investing [13]. There are also plenty of international tools for identifying ESG factors provided by such organizations as the United Nations Global Compact, the Global Reporting Initiative, the Climate Disclosure Standards Board, the Sustainability Accounting Standards Board, the International Integrated Reporting Council, and others [13].

Regulators are putting increasing emphasis on disclosure through sustainability reports, which may help to make ESG reporting more systemized and comparable for investors [14]. Companies that adopt the frameworks are becoming more comparable in that they represent information in the same way as it is prescribed by the guidance. Nevertheless, there is no one accepted guideline for publishing ESG information that could be at the same level of comparability as financial standards. Furthermore, the "comply or explain" basis of such regulations allows companies to avoid ESG reporting by simply explaining the reasons for omissions. Finally, the potential sanctions for not reporting ESG data or reporting with poor quality are not as clear as they are in financial reporting [15].

Furthermore, if in financial accounting there is a common understanding of comparability and many studies that evaluated it, no universally accepted methodology has been developed to evaluate the comparability of ESG data [16-23].

Considering the contextual framework and moving forward from the analysis of the existing literature, the aim of our research is to evaluate the intra-industry comparability of sustainability reports, framing the analysis on Global Reporting Initiative (GRI) Standards and discussing the results with the support of legitimacy and stakeholder theories.

Our research is focused on 41 GRI reports of listed oil and gas companies. We use reports prepared in accordance with GRI because it represents the most popular sustainability reporting framework among companies and the most used by researchers in analyzing the quality of ESG information. Oil and gas companies operate in a highly environmentally, economically, and socially sensitive industry and need to make a reasonable effort to disclose the ESG information required by regulators and other stakeholders. As long as these companies are listed, investors become a very powerful stakeholder group. Thus, companies feel pressure from investors to provide their ESG data to their peers. The choice of a homogeneous sample of companies makes our study on comparability more reliable.

We find that, despite the homogeneity of companies included in our sample, ESG data are still far from being comparable. This mainly depends on the absence of mandatory regulatory constraints in terms of social reporting. Companies prefer to use ESG disclosure to meet stakeholder's expectations and to legitimize themselves in the communities in which they operate rather than to comply with nonbinding rules. These results can explain the controversial results on the impact of ESG disclosure 
on a company's financial performance as stock returns and the cost of debt or the cost of equity. These findings show that making a comparison between sustainability reports is still very hard and that using these reports in empirical studies could be not helpful or may lead to biased estimates if these difficulties in comparability are not considered.

We think that our findings can be useful both for practitioners and regulators in the area of sustainability reporting. Practitioners have to use ESG data carefully when basing their investing decision on sustainable reports, and regulators could make new efforts in increasing the comparability of ESG data. We think that regulators could try to act at least at two different levels: motivating companies to allocate the sustainability governance body to a higher level of the corporate governance system and standardizing the legislation regarding the mandatory compliance of social disclosure.

The paper is organized as follows. The second section describes our research framework. The third part presents the methodology used to evaluate the level of comparability of ESG data. The fourth section shows the results of our empirical research, and the last part offers the conclusions, main results, and considerations for future researches.

\section{Literature Review and Contextual Framework}

Since long time academic literature has demonstrated a strong heterogeneity with reference to the disclosure of sustainability reports. The factors that can influence the different level of disclosure are grouped into three main categories concerning (1) the characteristics of the company, (2) corporate governance, and (3) the characteristics of the external context [24].

On the first front, among the company's characteristics, the relevant impacts of size and industry are highlighted.

With reference to the size, there are studies specifically dedicated to corporate finance in which it is highlighted that researchers receive significantly different or even opposite results when different size measures are used [25]. With specific regards to the relationship between the company dimension and sustainability disclosure, it is emphasized that as firm size increases, companies will increasingly report sustainability policies [26]. Larger organisations are attracting much more attention and scrutiny of a greater number of stakeholders. Moreover, they have more funds and labour opportunities to respond to these stakeholders, using more developed practices.

Concerning the industry, the type of operating sector certainly has an impact in the choices of ESG development, as shown in the study by Eccles et al. (2012) [27]. The paper shows that even such a widespread topic as climate change is disclosed differently depending on the sector. Such variation is explained by the difference in ESG materiality for industries: The demand from stakeholders is different, as well as the ability of the companies to influence the ESG issue. Deegan and Gordon (1996) also support the idea, stating that the quality of ESG disclosure depends on the activity of environmental lobby groups within certain industries [28].

The very extensive literature also argue about the impact of governance on the social responsibility development and sustainability reporting [29-33].

The most widespread and developed is the statement that the companies that institutionalize the concept of corporate social responsibility have a higher quality of sustainability reports. Cowen et al. (1987) found a positive relationship between the presence of the CSR (Corporate Social Responsibility) committee and the number of social disclosures [34]. Amran et al. (2014) stated that the integration of CSR in the vision and/or mission statement is positively associated with sustainability reporting quality [33]. Gary F. Peters and Andrea M. Romi (2015) described the correlation between the presence of a responsible person for CSR and corporate sustainability report assurance services [32].

Moreover, different levels of inclusion of stakeholders into corporate governance leads to the heterogeneous level of sustainability reports. The results of Khan et al. (2013) showed that that pressures exerted by external stakeholder groups (public ownership, foreign ownership, and managerial ownership in some cases) and corporate governance mechanisms involving independent 
outsiders (audit committee and board independence) may influence the ESG reporting practice [29]. Moreover, according to Amran et al. (2014), strategic alliances with nongovernmental organisations lead to the higher ESG transparency [33]. Jizi et al. (2013) stated that the board characteristics usually associated with the protection of shareholder interests (board independence and board size) are positively related to ESG disclosure [30]. Michelon and Parbonetti (2012) analysed the characteristics and background of the board members and discovered that the presence of community influentials (who have been previously identified as promoters of stakeholders engagement) among the board directors influences the sustainability reporting [31].

Concerning other board characteristics and their influence on ESG reporting, the results are quite controversial. Frank Li et al. (2016) studied the relationship between the power of CEOs and the firm's choice to engage in CSR highlighting: that high CEO pay slice, long CEO tenure, and CEO duality decrease the CSR activity of the company [35]. In contrast, Jizi et al. (2013) found that CEO duality impacts positively on CSR disclosure [30]. At the same time, some researchers argued a weak or no relation between board characteristics and the CSR reporting process [31,33].

With regards to the characteristics of the companies' context, the factors that are mainly reported in the literature are represented by the country of origin; the social, economic, and political context; and the cultural and stakeholder influence [24]. Very often, the country of origin appears as a relevant factor. Escobar et al. (2011) show that the normative context for sustainability reporting occurs at the country level rather than at the global one because sustainable development is largely a stakeholder-driven rather than a broad social pressure [36]. On this front, the study by Baldini et al. (2018) provides evidence that country-level characteristics such as a political system (legal framework and corruption), labour system (labour protection and unemployment rate), and cultural system (social cohesion and equal opportunities) significantly affect the firms' ESG disclosure practices [37].

All of the abovementioned factors influence the heterogeneity of ESG reporting through the difference in stakeholder activity or in the norms imposed by them. Firstly, the company's size and industry form the unique stakeholder surrounding and their requests for ESG transparency. Furthermore, the difference in a company's attention to stakeholders and their requests at the corporate governance levels [38,39] impacts the level of sustainability reporting. Finally, stakeholders from various countries impose distinct norms, including ESG reporting norms. Thus, a general support for the motivation of the heterogeneity in sustainability data can be generalised by stakeholder and legitimacy theories.

Legitimacy theory, which has been defined by Dowling and Pfeffer [40], is based on the common sense that the company operates inside the value system of society [41]. Central to the legitimacy theory is the concept of a social contract between organizations and members of a society $[42,43]$ that allows companies to operate as long as they meet the requirements imposed by society regarding the social and environmental impact of the business. If the society feels that the company does not fit its norms, it can impose sanctions in the form of restrictions on the firm's operations and resources and on the demand for its product [44]. Thus, the survival of an organization depends on whether it behaves in socially acceptable ways [45]. The company's desire to legitimize its activities inside the system in which it operates explains the motives of corporate managers to disclose the company value and strategy in the sphere of social and environmental activities [43]. In this case, sustainability reporting becomes a tool of legitimization of a company's activities [46,47]. ESG performance data become an entrance barrier to the market for companies where the legitimization effect is very high. From the point of view of this theory, the ESG disclosure demand is formed by the society that wants to limit the activities of the companies that do not fit some ESG benchmarks.

Concerning the stakeholder theory, first described by F. Edward Freeman [48], it takes as a basis the concept that the firm operates in an ongoing interaction with such parties as employees, local communities, suppliers, the natural environment, and other stakeholders. Stakeholders are the individuals or groups that are influenced by the company's activities and may have an influence on the company in return [49]. Such stakeholders are involved in creating the normative context in 
which firms act [50]. The role of ESG reporting in the framework of stakeholder theory is to inform the wide range of stakeholders about the company's operations in the field that is interesting to them. The stakeholders aggregate the ESG information to estimate the company's performance and to create their strategy of interacting with the company. The more the company's strategy responds to the stakeholders' inquires, the more favorable are the stakeholders' actions toward the company. Companies tend to use ESG information to manage or manipulate stakeholders to get their support for organizational survival [51].

Summarizing, these theories state that the modern company has to go beyond simple profit maximization and act in accordance with more than the law or market norms, taking into account the interests of the wide range of stakeholders. According to both the legitimacy and stakeholder theories, every company has its own values and stakeholders with different inquiries and demands. The relevant stakeholders and sources of legitimacy can potentially lead to very differentiated and heterogeneous information being provided. Consequently, from a general perspective, companies have their own unique demands for ESG data and the information. Thus, the ESG information that companies are asked to disclose may vary greatly.

The heterogeneity of ESG information is usually evaluated in terms of information quality. Researchers usually use credibility (or reliability) and relevance metrics when analyzing the quality of the information [18-20]. However, one of the vital qualitative characteristics-the comparability of the data-is usually omitted. Such avoidance of the comparability metric can be connected with the fact that even if comparability is determined to be a qualitative characteristic of the information, the analysis remains complex, sensitive, and subjective [16,20].

In this paper, we deal with comparability-a particular qualitative characteristic of sustainability reporting disclosure representing the heterogeneity of reporting. The most common view of comparability as a general term originated in the United States and holds that comparability is achieved by assuring that "like things look alike, and unlike things look different" [16,52]. To be more precise and to address comparability in terms of information, it is accepted as one of the qualitative characteristics of reporting that enhances the usefulness of accounting information $[21,53]$

The concept of accounting comparability is quite developed in financial reporting. From the point of view of financial accounting, if two firms have similar economic outcomes and report similar accounting figures, their accounting is comparable [53,54]. However, ESG reporting is not at the same stage of development when the outcomes can be compared with the accounting figures as long as there is no direct link between the ESG information and the measures of performance. Thus, the more general concept of comparability should be used for sustainability reports.

The more general notion of comparability, that is suitable for ESG information, can be derived from regulations, mandatory or voluntary $[15,16]$. Mandatory regulations may be implemented through the state directives on reporting practices or the stock exchange guidance or listing requirements. Voluntary regulations can be related to nonfinancial reporting frameworks and standards. The most widespread standards are IFRS (issued by IASB) and US GAAPs (issued by FASB) in financial reporting and GRI in sustainable accounting [13]. Moreover, as ESG reporting is in a stage of development, many sustainability reporting frameworks have as much influence as the standards and present their conceptual view of comparability $[13,55]$. To this extent, we can consider the International Integrated Reporting Framework $(<\mathrm{IR}>)$, the Climate Disclosure Standards Board (CDSB), the Sustainability Accounting Standards Board (SASB), and the Financial Stability Board (FSB) Task Force on Climate-Related Financial Disclosures (TCFD).

Table 1 shows the main references related to the concept of comparability as it is understood by these financial and sustainable accounting standards and frameworks.

A common feature of these prescriptions is that comparability is considered as a qualitative characteristic of the reporting information. This characteristic is basically associated with the consistency of the figures over time and the ability to compare the information with other organizations. 
Table 1. The concepts of comparability according to financial and sustainable accounting.

\begin{tabular}{l}
\hline Standard/Framework \\
\hline \\
IASB conceptual framework for financial \\
reporting, Chapter 3, QC20-25 \\
FASB conceptual framework for \\
financial reporting, Chapter 3, QC20-25
\end{tabular}

Concepts of Comparability

"Comparability is the qualitative characteristic that enables users to identify and understand similarities in, and differences among, items." "Some degree of comparability is likely to be attained by satisfying the fundamental qualitative characteristics."

"Although a single economic phenomenon can be faithfully represented in multiple ways, permitting alternative accounting methods for the same economic phenomenon diminishes comparability."

"Comparisons between organizations require sensitivity to factors such as the organizations' size, geographic influences, and other considerations that can affect the relative performance of an organization. When necessary, it is important to provide context that helps report users understand the factors that can contribute to

Global Reporting Initiative (GRI) differences in impacts or performance between organizations.

Standards, GRI101: Foundation The organization is expected to include total numbers (that is, absolute data, such as tons of waste) as well as ratios (that is, normalized data, such as waste per unit of production) to enable analytical comparisons." "The reporting organization's performance can be compared with appropriate benchmarks. When they are available, the report utilizes generally accepted protocols for compiling, measuring, and presenting information, including the information required by the GRI Standards."

"The specific information in an integrated report will, necessarily, vary from one organization to another because each organization creates value in its own unique way. Nonetheless, addressing the questions relating to the Content Elements, which apply to all organizations, helps ensure a suitable level of comparability between organizations."

Integrated Reporting Framework $(<\mathrm{IR}>)$ Framework, Part II, Chapter 3, G "Other powerful tools for enhancing comparability can include using benchmark data, such as industry or regional benchmarks, presenting information in the form of ratios (e.g., research expenditure as a percentage of sales or carbon intensity measures such as emissions per unit of output), [and] reporting quantitative indicators commonly used by other organizations with similar activities, particularly when standardized definitions are stipulated by an independent organization."

"Comparability is the qualitative characteristic of information that enables users to identify similarities in, and differences between, two sets of information."

Climate Disclosure Standards Board (CDSB) Framework, Chapter 2, P4 "Comparability greatly enhances the value of information to investors and is therefore the objective of this requirement."

"In the early years of adoption, it is recognised that comparability of material environmental information between organizations and sectors may be limited, pending development of common disclosure approaches, policies, and practices."

"At the level of accounting metrics, the SASB considers the following set of criteria when evaluating potential metrics to measure performance on

Sustainability Accounting Standards Board (SASB) Framework, Chapter 4

Financial Stability Board (FSB) Task Force on Climate-Related Financial Disclosures (TCFD), Appendix 3 aspects of each sustainability topic: [ ... ] Comparable Metrics will yield primarily (a) quantitative data that allow for peer-to-peer benchmarking within the industry and year-on-year benchmarking for an issuer but also (b) qualitative information that facilitates [the] comparison of disclosure."

"Principle 5: Disclosures should be comparable among organizations within a sector, industry, or portfolio. Disclosures should allow for meaningful comparisons of strategy, business activities, risks, and performance across organizations and within sectors and jurisdictions. The level of detail provided in disclosures should enable comparison and benchmarking of risks across sectors and at the portfolio level, where appropriate. The placement of reporting would ideally be consistent across organizations-i.e., in financial filings-in order to facilitate easy access to the relevant information." 
However, a profound difference between financial accounting and sustainable accounting remains, for the following reasons [15].

First, following certain standards in financial accounting is mandatory, and this implies the relevant risk of sanctions. In contrast to financial reporting, it is not clear what the potential sanctions resulting from nondisclosure would be in the case of sustainability reporting, and it is also unclear what enforcement and monitoring systems could incentivize firms to actually increase ESG disclosure.

Second, in sustainability accounting, there is no clear guidance on the metrics and disclosure that a firm needs to quantify and disclose. Moreover, the firms that have already been disclosing some ESG information might state that the preexisting disclosure patterns are sufficient and that they will not change their level of disclosure.

Third, whereas firms in the financial reporting context have little ability to deviate from the default option of providing reporting according to some GAAP, the sustainability context allows the testing of whether firms proactively seek these properties and increase the level of comparability in an unregulated setting. In light of the stated benefits of disclosure credibility and comparability in a financial reporting context, some scholars [15] argue, "these benefits will be at least as significant and likely to be even more significant in a sustainability setting."

Consequently, providing a relevant set of comparable ESG and sustainability information is, on the one hand, more difficult for both the nature of the information and the regulatory process in respect to financial accounting. On the other hand, it can have greater value, since it represents an excellent signal of their commitment to maintaining transparency and their willingness to be responsible and accountable.

In other words, the structural heterogeneity of sustainable (as seen before) disclosure should find a point of balance with the need for comparability. In our theoretical hypothesis, these points of balance could be the operating industry and the interaction with financial markets. Indeed, considering the features of each company's specific business environment, these contextual conditions can mitigate the heterogeneity of information and increase the level of comparability of sustainability reports.

The first condition can be related to the operating industry in which the companies compete. Sectors unite companies with similar operations, business models, influences on society, and environmental impacts and with the same or similar circumstances or stakeholder groups. If stakeholders are almost the same and the source of legitimacy is more homogeneous, their ESG data requests should also be homogeneous and comparable. This makes comparability an important issue in both frameworks, the legitimacy theory and the stakeholder theory. Thus, the authors suggest that the industry specification may have a great impact on comparability. Therefore, comparability may seem difficult to implement, but in practice, it can be more important for companies operating in the same industry. To this extent, the GRI elaborated some standards of disclosure devoted to specific industries [63], correlating the relevant information needs of stakeholders with the peculiar features of the environmental and industrial characteristics of the sector. GRI industry supplements can potentially play a very important role in assuring an adequate level of comparability in sustainability reports.

The second contextual condition is the governance interaction with financial markets that occurs when the company is listed. Adopting the theoretical lens of the legitimacy theory, in listed companies, the social contract between organizations and members of society is mediated and emphasized by financial investors. Especially now, in light of the growing relevance of responsible investing, the financial market premium can be considered an indirect source of legitimacy that can mutually leverage the impact of sustainability and economic performance for the whole society. Similar conditions also can be consistent with stakeholder theory, where stakeholders create the normative context in which firms act [50]. For a listed company, relevant stakeholders are undoubtedly represented by financial investors. As a general rule, the more the company's strategy can respond to the growing demand for information on sustainable performance, the more favorable the financial investors' attitude toward the company. 
As a result, supported by the two theoretical perspectives presented, a fundamental characteristic of this demand is the comparability of information. Consequently, while recognizing the differences between financial and sustainable accounting and taking into account the structural heterogeneity of sustainable disclosure, we expect to observe a certain level of comparability of sustainability reports elaborated by listed companies that operate in the same industry.

Moving forward from this literature review and contextual framework, the aim of our research is to evaluate the intra-industry comparability of sustainability reports, framing the analysis on GRI Standards and discussing the results with the support of the legitimacy and stakeholder theories.

\section{Research Design and Materials}

\subsection{Methods and Data Collection}

The methodological approach adopted in this study is broadly qualitative, although some elements of quantitative research are employed where appropriate.

In the general ontological and epistemological position adopted here, the research design provides a framework for the collection and analysis of data, reflecting a decision about the priority being given to a range of dimensions of the research process. Research method defines the technique for collecting data and specifies a specific approach to investigate the issue of ESG data comparability on an empirical basis.

Considering that our research poses "what" questions, has no control over behavioral events, and is focused on a contemporary phenomenon, the most appropriate methodology is an exploratory case study, using a multiple cases approach in order to strengthen the empirical findings and to make interpretations more robust [64]. This approach embodies the logic of comparison in that it implies that we can understand social phenomena better when they are compared to two or more meaningfully contrasting cases or situations.

In this study, reports prepared in accordance with the most popular sustainability reporting framework, the Global Reporting Initiative (GRI), were chosen [65]. Ther are approximately 50,559 GRI reports from over 90 countries in the GRI Database [66], helping to capture a large dataset for the research. GRI reports are generally used by researchers in analyzing the quality of ESG information [24].

The reports for the research were chosen with the help of the full list of GRI reports for 2017, accumulated from the GRI database. The reporting period for the research is 2016.

Given the explanatory nature of the research, this study conducted a purposeful sampling of the companies operating in one specific industry: the oil and gas industry.

The oil and gas industry is supposed to be one of the most sensitive to ESG issues [20,67]. Moreover, society compares the impact of oil and gas companies with their rivals: renewable and alternative energy companies [68]. Thus, the ESG data of oil and gas companies are supposed to be tracked more and used in investment decision-making when comparing to other industries [67].

Additionally, the oil and gas sector is one of the most important sectors in the world. According to the World Bank, this sector currently makes up $1.019 \%$ of the global gross domestic product (GDP) of USD 75,937 trillion [69]. Concerning the whole energy industry, the oil and gas sector accounts for around $63 \%$ of the world's commercial energy mix [69]. The volatility of oil prices can cause macroeconomic financial instability [70] and, in turn, political and social shocks. The outstanding impact of the oil and gas industry makes society more conscious about these companies and imposes higher demands for ESG transparency. Thus, it is expected that the amount of ESG reports will grow and their quality will be very good, allowing a sufficient sample to be built for the research [71].

Moreover, the oil and gas industry is international, which is important for exploratory purposes. Among the oil and gas companies in the GRI database that prepare reports with the GRI oil and gas supplement, there are companies from Europe, Asia, Latin America, North America, Oceania, and Africa. 
The oil and gas industry was also chosen for the research because it comprises big companies that obviously produce ESG reports. The companies with the GRI oil and gas supplement are usually large or multinational large organizations (66 companies out of 68) with a headcount equal to or above 250 and a turnover of more than 50 million EUR or total assets more than 43 million. The large scale of the organizations means that they have more groundbreaking impact on the environment and local communities, which increases the need for sustainability reports. Thus, the number of sustainability reports in this sector is expected to be sufficient for the research.

With the aim to determine oil and gas firms, only companies with the GRI Oil and Gas Supplement were chosen. The GRI Oil and Gas Supplement was developed to capture the issues that matter most to companies in this sector. This helps to highlight only companies with very close business operations and stakeholders. The comparability of the data for such a group of companies should be higher, as stakeholder surrounding is homogeneous.

Only listed companies were taken into consideration in this work, in order to reinforce the role of financial markets in company activities. It is assumed that for the listed companies, the main stakeholders are shareholders and investors, for whom the comparability of the ESG data are of paramount importance.

Companies with reports in English were chosen, as English is commonly used by investors from any country, while reports in local languages can be used only in one country.

Nonfinancial reports were chosen as the main source of ESG information, as they are considered to contain primary ESG information in the most overwhelming and reliable way. The reports are public documents that make the ESG data available for any analytical bodies or investors. Moreover, the reports contain primary information from companies that they confirm to be reliable. This research implemented a content analysis of the reports, while most previous works concentrated on the characteristics of the reports themselves $[18,19]$. This allowed us to analyze the data in detail. With the aim of analyzing the details, other researchers use secondary data sources or data generators, such as Bloomberg LP [72]. However, data aggregators usually have limited access that limits the availability of the data. Moreover, data aggregators limit the company in representing the information according to particular indicators. Thus, not all information from the companies is available in such databases.

Based on the GRI requirements, the report can be either an integrated or separate sustainability report; thus, both these formats were taken for the research.

Both the current GRI Standards and the previous version, GRI G4 Guidelines, were taken for consideration, as changes in the new standards were concerned with only interpretation matters. GRI provides the crosslinks between indicators from the G4 Guidelines and the Standards, stating that indicators from both papers are equivalent [31].

We obtained 41 companies (Table 2) with all of the abovementioned requirements implemented in their reports and reports that were available publicly at the time of this research (one company did not provide access to the data anymore; thus, it was excluded despite meeting all the requirements).

As it was assumed in the selection logic, the majority of the companies (95\%) are large or multinational enterprises with a headcount equal to or above 250 and a turnover of more than 50 million EUR or total assets more than 43 million. Considering in more detail these fundamentals-the mostly relevant in the GRI framework-the majority of the companies shows a substantial homogeneity. Over $75 \%$ of the companies are characterized by a number of employees less than 30 thousand, and only $15 \%$ reach a headcount over 50 thousand. The turnover remains under 25 billion in $78 \%$ of the companies, and the total assets are less than 25 billion in $70 \%$ of the cases.

As for the ownership, $81 \%$ of the companies are private. The companies are from 24 countries in 6 regions. The most represented macro region, Europe, has companies mainly in the Russian Federation $(24 \%)$, Great Britain and Northern Ireland (14\%), and Spain (10\%). The second most represented region, Asia, mainly has companies in Thailand (50\%) and India (25\%). The reports of the sample companies are mainly not integrated (83\%), prepared with a core level of adherence to the GRI (68\%). 
Table 2. The sample of 41 companies in the oil and gas industry.

\begin{tabular}{|c|c|c|}
\hline & No. of Companies in the Sample & $\%$ \\
\hline \multicolumn{3}{|l|}{ Characteristics } \\
\hline \multicolumn{3}{|l|}{ Size: } \\
\hline Large Enterprises & 31 & $75.6 \%$ \\
\hline Multinational Enterprises & 8 & $19.5 \%$ \\
\hline Small and Medium Enterprises & 2 & $4.9 \%$ \\
\hline \multicolumn{3}{|l|}{ Ownership: } \\
\hline Private & 33 & $80.5 \%$ \\
\hline State-owned (or subsidiary) & 8 & $19.5 \%$ \\
\hline \multicolumn{3}{|l|}{ Region: } \\
\hline Africa & 1 & $2.4 \%$ \\
\hline Asia & 12 & $29.3 \%$ \\
\hline Europe & 21 & $51.2 \%$ \\
\hline Northern America & 4 & $9.8 \%$ \\
\hline Southern America & 1 & $2.4 \%$ \\
\hline Oceania & 2 & $4.9 \%$ \\
\hline \multicolumn{3}{|l|}{ Reporting form } \\
\hline \multicolumn{3}{|l|}{ GRI accordance: } \\
\hline Undeclared & 5 & $12.3 \%$ \\
\hline Citing GRI & 1 & $2.4 \%$ \\
\hline Core & 28 & $68.3 \%$ \\
\hline Comprehensive & 7 & $17.0 \%$ \\
\hline \multicolumn{3}{|l|}{ Integrated Reporting: } \\
\hline Yes & 7 & $17.0 \%$ \\
\hline No & 34 & $83.0 \%$ \\
\hline
\end{tabular}

Source: Compiled by the authors on the basis of GRI Reports List and companies' sustainability reports.

\subsection{Analytical Framework: Stages of the Research}

As the basis for the analytical framework, the GRI Standards were chosen, as their main aim is to enhance the global comparability and quality of information on ESG impacts, which makes this framework very relevant to the aims of the research [31]. The format of the GRI Standards allows for the standardization of corporate social and environmental reporting [21]. It includes a modular interrelated structure on a range of environmental, economic, and social impacts. Furthermore, despite the GRI being a self-sufficient framework, it has connections with other reporting and sustainability policies and frameworks, which makes it a comprehensive standard. GRI collaborates with the following organizations: the Organization for Economic Cooperation and Development, the UN Environment Program, the UN Global Compact, Carbon Disclosure Project (CDP), the International Organization for Standardization's ISO 26000, the International Finance Corporation, the UN Conference on Trade and Development, and the Earth Charter Initiative [73]. Moreover, the GRI framework is not exclusionary: Other frameworks may be used at the same time to prepare GRI reports. This allows mixed reports that are prepared in accordance with several frameworks to be included.

While estimating the level of comparability, the units of information should be determined that will form the sample for the estimation. Some researchers who estimate the qualitative characteristics of the report choose the level of particular elements, such as strategy or assurance statement [20]. Unlike previous work, this study focuses on the most precise units of information. GRI reports have the following units: categories (series in GRI Standards), aspects (topics in GRI Standards), and indicators (disclosures in GRI Standards). For example, the environmental category (module) includes such aspects (topics) as water, biodiversity, emissions, effluents and wastes, and some others. Each aspect (topic), in turn, has a set of indicators; for example, indicator G4-EN8: Water withdrawal by source. This research is focused on the indicators as the most precise unit of reported data.

The evaluation of the level of comparability should be undertaken in four stages, with a preliminary zero stage (Table 3$)$. 
Table 3. The stages of analysis.

\begin{tabular}{|c|c|c|c|}
\hline $\begin{array}{c}\text { Stages } \\
\text { Comparability }\end{array}$ & Criteria & Reference & Output \\
\hline Stage 0 & $\begin{array}{l}\text { Include all listed companies operating in the oil } \\
\text { and gas industry with sustainability reports }\end{array}$ & $\begin{array}{l}\text { GRI Reports List of oil } \\
\text { and gas companies }\end{array}$ & $\begin{array}{c}\text { Sample } 0 \\
\text { Oil } \\
\text { and gas sustainability } \\
\text { reports }\end{array}$ \\
\hline Stage 1 & $\begin{array}{l}\text { Availability of the correlation between material aspects } \\
\text { and GRI aspects of companies in Sample } 0\end{array}$ & GRI framework & $\begin{array}{c}\text { Subsample } 1 \\
\text { Comparable reports }\end{array}$ \\
\hline Stage 2 & $\begin{array}{l}\text { Analysis of material aspects reported by companies in } \\
\text { subsample } 1\end{array}$ & GRI framework & $\begin{array}{l}\text { Subsample } 2 \\
\text { Selection of most } \\
\text { reported material } \\
\text { aspects }\end{array}$ \\
\hline Stage 3 & $\begin{array}{l}\text { Analysis of indicators used by companies for material } \\
\text { aspects in subsample } 2\end{array}$ & GRI framework & $\begin{array}{l}\text { Subsample } 3 \\
\text { Selection of most } \\
\text { reported indicators }\end{array}$ \\
\hline Stage 4 & $\begin{array}{ll}\text { Qualitative characteristics of indicators in subsample 3: } \\
\text { 1. } \\
\text { 2. } & \text { Quantext and description (GRI, SASB, TCFD) } \\
\text { 3. } & \text { Total number and ratios (GRI, }<\mathrm{IR}>\text { ) } \\
\text { 4. } & \text { Reporting period (GRI) } \\
\text { 5. } & \text { Benchmarks (GRI, }<\mathrm{IR}>\text { ) } \\
\text { 6. } & \text { Breakdown of numbers (TCFD) } \\
\text { 7. } & \text { Disclosure method (US GAAPs, IFRS, CDSB) } \\
\text { 8. } & \text { Generally accepted measures for total numbers (GRI) }\end{array}$ & $\begin{array}{l}\text { GRI framework } \\
\text { and other reporting } \\
\text { standards } \\
\text { and frameworks }\end{array}$ & $\begin{array}{l}\text { Qualitative } \\
\text { characteristics of } \\
\text { indicators for } \\
\text { comparability }\end{array}$ \\
\hline
\end{tabular}

Source: Compiled by the authors.

The estimation of the comparability of indicators should start with a determination of the materiality. According to the GRI Standards, the materiality principle prescribes that organizations should concentrate on aggregating the information that "reflects a reporting organization's significant economic, environmental, and social impacts or that substantively influences the assessments and decisions of stakeholders" [31]. These material issues are supposed to be described more precisely and with the use of GRI indicators. Thus, the GRI indicators for the analysis can be used only within material topics. Because of this, at the first stage of comparability analysis, the ability to compare the materiality was checked. GRI prescribes linking the company's material aspects and the GRI aspects. The correlation with GRI helps to determine the comparable boundaries of the material aspects and to describe them in accordance with generally accepted methodology. Only those companies that have links between their material aspects and the GRI aspects were selected for further analysis.

The second stage determines the sample of potentially comparable material aspects, the broadest data classification unit in accordance with GRI. As the interest of this research is in the comparability of the whole industry, only those aspects that appear in all or a majority of the companies were chosen for the analysis. The result of the second stage is the sample of potentially comparable aspects.

The third stage goes from the aspect level to the analysis of the most widespread indicators. It is vital to note that the indicators are of special importance in evaluating the quality of reporting as they allow to measure the impact produced in the three areas of sustainability [74]. GRI does not oblige companies to disclose all the indicators from the material aspect, when selecting the in accordance core option. It is enough to disclose at least one. Thus, there may be differences in the disclosure of the aspect. The set of the most widespread indicators is chosen at this stage.

The fourth stage goes into more detail and analyzes the indicators themselves. At this stage, the level of comparability of the indicators is estimated. The level of comparability is a qualitative characteristic of the reporting data; thus, the method of measuring it may be the same as for the other qualitative characteristics. In the majority of the papers, the quality is determined as the compliance of the object with certain standards or criteria [17-20]. The criteria are derived from the concept of comparability provided by standards and reporting frameworks [13,34]. Only the criteria for cross-company comparability were taken into account in this research, and not comparability over 
time. The result of this stage is the estimated level of comparability and the sample of most comparable indicators for the industry.

\section{Results}

The four stages of the research on the level of comparability are based on the sample of GRI reports that was built at Stage 0. This stage is described above in Section 3.1. Methods and Data Collection. The result of Stage 0 is the sample of 41 GRI reports of listed oil and gas companies.

Stage 1 defines the reports that are potentially comparable. The measure of comparability is the ability to make a correlation between the report's aspects and GRI aspects. Despite the GRI prescriptions, only 16 out of 41 companies (39\%) describe the correlation between their material aspects and the GRI aspects.

Of the 16 companies (Table 4) that have a correlation with the GRI aspects, the majority (94\%) are large or multinational companies with a headcount equal to or above 250 and a turnover of more than 50 million EUR or total assets more than 43 million. Moreover, $81 \%$ of the companies are private. The companies are from 11 countries, instead of the 24 in the initial sample, representing 4 regions instead of the initial 6. The most widespread regions are still Asia (44\%) and Europe (37\%). It is supposed that companies from Africa, Latin America, and the Caribbean are incomparable in the first stage. The largest number of companies are located in Thailand (57\% of companies in Asia) and Russia (50\% of companies in Europe). The reports of the sample companies are mainly not integrated $(94 \%)$, prepared in accordance core to the GRI (81\%).

Table 4. The characteristics of subsample 1 compared with the sample of oil and gas companies.

\begin{tabular}{|c|c|c|c|}
\hline & \multicolumn{2}{|c|}{ Subsample 1: Comparable Companies } & \multirow{2}{*}{$\begin{array}{l}\% \text { of Sample of Oil } \\
\text { and Gas Companies }\end{array}$} \\
\hline & No. of Companies & $\%$ & \\
\hline \multicolumn{4}{|l|}{ Characteristics } \\
\hline \multicolumn{4}{|l|}{ Size: } \\
\hline Large Enterprises & 13 & $81.2 \%$ & $75.6 \%$ \\
\hline Multinational Enterprises & 2 & $12.5 \%$ & $19.5 \%$ \\
\hline Small and Medium Enterprises & 1 & $6.3 \%$ & $4.9 \%$ \\
\hline \multicolumn{4}{|l|}{ Ownership: } \\
\hline Private & 13 & $81.2 \%$ & $80.8 \%$ \\
\hline State-owned & 3 & $18.8 \%$ & $19.5 \%$ \\
\hline \multicolumn{4}{|l|}{ Region: } \\
\hline Africa & 0 & - & $2.4 \%$ \\
\hline Asia & 7 & $43.7 \%$ & $29.3 \%$ \\
\hline Europe & 6 & $37.5 \%$ & $51.2 \%$ \\
\hline North America & 2 & $12.5 \%$ & $9.8 \%$ \\
\hline South America & 0 & - & $2.4 \%$ \\
\hline Oceania & 1 & $6.3 \%$ & $4.9 \%$ \\
\hline \multicolumn{4}{|l|}{ Reporting choice } \\
\hline \multicolumn{4}{|l|}{ GRI accordance: } \\
\hline Undeclared & 1 & $6.3 \%$ & $12.3 \%$ \\
\hline Citing GRI & 0 & $0.0 \%$ & $0.0 \%$ \\
\hline Core & 13 & $81.2 \%$ & $70.7 \%$ \\
\hline Comprehensive & 2 & $12.5 \%$ & $17.0 \%$ \\
\hline \multicolumn{4}{|l|}{ Integrated Reporting: } \\
\hline Yes & 1 & $6.3 \%$ & $17.0 \%$ \\
\hline No & 15 & $93.7 \%$ & $83.0 \%$ \\
\hline
\end{tabular}

Source: Compiled by the authors on the basis of GRI Reports List and companies' sustainability reports.

The correlation between the material aspects and the GRI aspects is developed through different technical forms (Table 5) in which the choice of providing a separate table (44\%) and a correlation with the indicators $(25 \%)$ prevails. 
Table 5. The forms of the description of the correlation between the material aspects and the GRI aspects.

\begin{tabular}{ccc}
\hline Forms & Number of Companies & $\%$ \\
\hline Separate table & 7 & $43.7 \%$ \\
Correlation with GRI indicators & 4 & $25.0 \%$ \\
Material aspects coincide with GRI aspects & 3 & $18.7 \%$ \\
GRI content index & 2 & $12.5 \%$ \\
Total & $\mathbf{1 6}$ & $\mathbf{1 0 0 . 0 \%}$ \\
\hline
\end{tabular}

Source: Compiled by the authors on the basis of GRI Reports List.

The companies that do not describe the correlation between their material aspects and the GRI aspects can be divided into two groups: those with their own aspects that are not correlated with GRI aspects ( 23 companies) and those that did not determine their material aspects at all ( 2 companies).

The second step in determining the level of comparability among companies is to conduct a qualitative analysis of the most relevant aspects for the industry. This step was implemented on the basis of determining 16 companies because only the topics of these companies can be comparably defined.

There are 10 aspects that appear in more than $50 \%$ of companies (Appendix A). There is no aspect that is relevant for all 16 companies. Moreover, there are two aspects that are not disclosed by any company: investment (in human rights) and involuntary resettlement (oil and gas supplement). The most relevant topics for the industry are emissions (88\%), occupational health and safety $(88 \%)$, effluents and waste $(81 \%)$, and economic performance $(75 \%)$. The topics cover all the spheres of the triple bottom-line performance: ecological (emissions and effluents and waste), economical (economic performance), and social (occupational health and safety). These topics cover such main stakeholders as ecological nonfinancial organizations and local communities, investors, and employees.

The terms for the aspects, even the most relevant ones, vary from company to company. Some prefer to use terms in accordance with the GRI. Some companies use more precise terms $\left(\mathrm{CO}_{2}\right.$, $\mathrm{SO}_{2}, \mathrm{NOX}, \mathrm{VOC}$, and particulate matter emissions), and others use more general terms (environmental management). While some companies prefer to disclose all aspects together (Denbury, Elnusa, etc.), others separate them and disclose them in different parts of the report (Lukoil, Thai Oil, etc.).

In the third stage of the analysis, the most widespread indicators were determined. Each GRI aspect includes several indicators for disclosure. The company can choose one or more for disclosure, which creates differences between companies. The most relevant material aspects for the industry include 23 GRI indicators, and their implementation varies from $29 \%$ to $100 \%$ of the companies. Eight relevant indicators out of 23 were chosen for further analysis (Appendix B). Each indicator appears in reports of more than $75 \%$ of the companies for which the aspect is material. All four material aspects are represented by the most widespread indicators.

The indicators present information on such topics as direct (Scope 1) and indirect (Scope 2) greenhouse gas (GHG) emissions; NOX, SOX, and other significant air emissions; water discharge, waste, and significant spills; rates of injury, occupational disease, lost days, and absenteeism; and direct economic value generated and distributed between the company's stakeholders. The indicators represent the general information on the company's impact in the chosen material aspects. The most widespread topic concerns GHG emissions, which is the main issue for oil and gas companies: Energy fuel is in the top three areas of scientific research concerning carbon reduction and technology [75]. Notably, companies do not usually perform on sector-specific indicators from the oil and gas supplement, such as the volume and disposal of formed or produced water, the volume of flared and vented hydrocarbon, the amount of drilling waste (drill mud and cuttings), and the strategies for treatment and disposal.

In the fourth stage of the research, the most widespread indicators were analyzed with the help of eight criteria of comparability derived from nonfinancial reporting frameworks and standards (Table 6). 
Table 6. The comparability of sustainability information in oil and gas companies: a stages approach.

\begin{tabular}{|c|c|c|c|c|c|c|c|c|c|c|c|}
\hline \multirow[b]{2}{*}{ 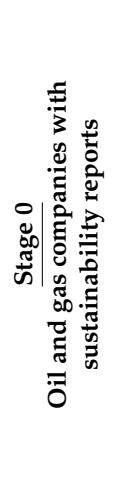 } & \multirow[b]{2}{*}{ 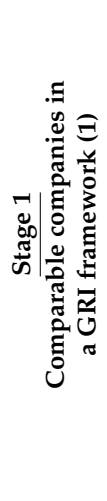 } & \multirow[b]{2}{*}{ 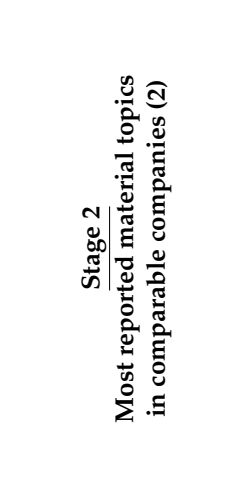 } & \multirow[b]{2}{*}{ 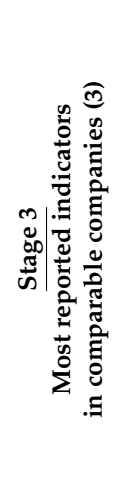 } & \multicolumn{8}{|c|}{$\frac{\text { Stage } 4}{\text { Qualitative characteristics of comparability (4) }}$} \\
\hline & & & & 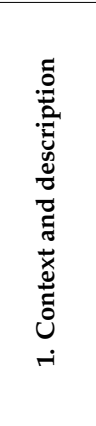 & 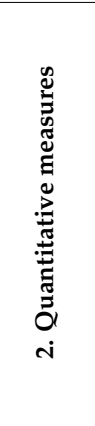 & 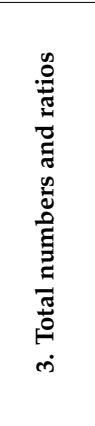 & 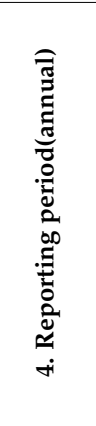 & 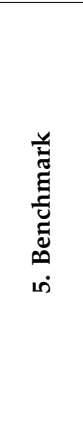 & 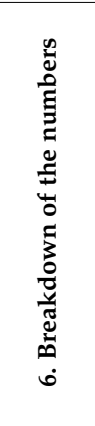 & 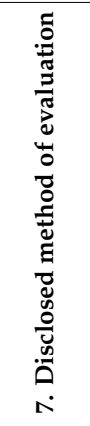 & 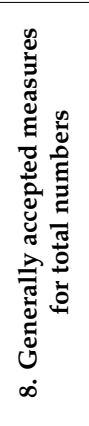 \\
\hline \multirow{8}{*}{$\begin{array}{c}\# 41 \\
(100 \%)\end{array}$} & \multirow{8}{*}{$\begin{array}{l}\# 16 \\
(39 \%)\end{array}$} & \multirow{3}{*}{$\begin{array}{c}\text { Emissions } \\
\quad \# 14 \\
(87 \%)\end{array}$} & $\begin{array}{c}\text { G4-EN15 } \\
\# 12 \\
(85 \%)\end{array}$ & $\begin{array}{c}\# 12 \\
(100 \%)\end{array}$ & $\begin{array}{c}\# 12 \\
(100 \%)\end{array}$ & $\begin{array}{c}\# 9 \\
(75 \%)\end{array}$ & $\begin{array}{c}\# 12 \\
(100 \%)\end{array}$ & $\begin{array}{l}\# 6 \\
(50 \%)\end{array}$ & $\begin{array}{l}\# 11 \\
(92 \%)\end{array}$ & $\begin{array}{c}\# 11 \\
(92 \%)\end{array}$ & $\begin{array}{c}\# 12 \\
(100 \%)\end{array}$ \\
\hline & & & $\begin{array}{c}\text { G4-EN16 } \\
\text { \#11 } \\
(79 \%)\end{array}$ & $\begin{array}{c}\# 11 \\
(100 \%)\end{array}$ & $\begin{array}{c}\# 11 \\
(100 \%)\end{array}$ & $\begin{array}{c}\# 7 \\
(64 \%)\end{array}$ & $\begin{array}{c}\# 11 \\
(100 \%)\end{array}$ & $\begin{array}{l}\# 5 \\
(45 \%)\end{array}$ & $\begin{array}{c}\# 11 \\
(100 \%)\end{array}$ & $\begin{array}{l}\# 10 \\
(91 \%)\end{array}$ & $\begin{array}{c}\# 11 \\
(100 \%)\end{array}$ \\
\hline & & & $\begin{array}{c}\text { G4-EN21 } \\
\# 12 \\
(85 \%)\end{array}$ & $\begin{array}{c}\# 12 \\
(85 \%)\end{array}$ & $\begin{array}{c}\# 11 \\
(92 \%)\end{array}$ & $\begin{array}{c}\# 7 \\
(58 \%)\end{array}$ & $\begin{array}{l}\# 10 \\
(83 \%)\end{array}$ & $\begin{array}{l}\# 3 \\
(25 \%)\end{array}$ & $\begin{array}{c}\# 10 \\
(83 \%)\end{array}$ & $\begin{array}{c}\# 4 \\
(33 \%)\end{array}$ & $\begin{array}{l}\# 10 \\
(83 \%)\end{array}$ \\
\hline & & $\begin{array}{c}\text { Occupational Health } \\
\text { and Safety } \\
\# 14 \\
(87 \%)\end{array}$ & $\begin{array}{c}\text { G4-LA6 } \\
\text { \# 14 } \\
(100 \%)\end{array}$ & $\begin{array}{c}\# 14 \\
(100 \%)\end{array}$ & $\begin{array}{c}\# 14 \\
(100 \%)\end{array}$ & $\begin{array}{c}\# 14 \\
(100 \%)\end{array}$ & $\begin{array}{c}\# 14 \\
(100 \%)\end{array}$ & $\begin{array}{l}\# 2 \\
(14 \%)\end{array}$ & $\begin{array}{c}\# 14 \\
(100 \%)\end{array}$ & $\begin{array}{c}\# 10 \\
(71 \%)\end{array}$ & $\begin{array}{c}\# 14 \\
(100 \%)\end{array}$ \\
\hline & & \multirow{3}{*}{$\begin{array}{c}\text { Effluents and Waste } \\
\quad \# 13 \\
(81 \%)\end{array}$} & $\begin{array}{c}\text { G4-EN22 } \\
\text { \#11 } \\
(85 \%)\end{array}$ & $\begin{array}{c}\# 11 \\
(100 \%)\end{array}$ & $\begin{array}{c}\# 11 \\
(100 \%)\end{array}$ & $\begin{array}{c}\# 4 \\
(36 \%)\end{array}$ & $\begin{array}{c}\# 11 \\
(100 \%)\end{array}$ & $\begin{array}{c}\# 2 \\
(18 \%)\end{array}$ & $\begin{array}{c}\# 8 \\
(73) \%\end{array}$ & $\begin{array}{c}\# 4 \\
(36 \%)\end{array}$ & $\begin{array}{c}\# 10 \\
(91 \%)\end{array}$ \\
\hline & & & $\begin{array}{c}\text { G4-EN23 } \\
\# 11 \\
(85 \%)\end{array}$ & $\begin{array}{c}\# 11 \\
(100) \%\end{array}$ & $\begin{array}{c}\# 11 \\
(100 \%)\end{array}$ & $\begin{array}{c}\# 1 \\
(9 \%)\end{array}$ & $\begin{array}{c}\# 11 \\
(100 \%)\end{array}$ & $\begin{array}{c}\# 1 \\
(9 \%)\end{array}$ & $\begin{array}{c}\# 11 \\
(100 \%)\end{array}$ & $\begin{array}{c}\# 4 \\
(36 \%)\end{array}$ & $\begin{array}{c}\# 11 \\
(100 \%)\end{array}$ \\
\hline & & & $\begin{array}{c}\text { G4-EN24 } \\
\quad \# 11 \\
(85 \%) \\
\end{array}$ & $\begin{array}{c}\# 8 \\
(73 \%)\end{array}$ & $\begin{array}{c}\# 10 \\
(91 \%)\end{array}$ & $\begin{array}{c}\# 2 \\
(18 \%)\end{array}$ & $\begin{array}{c}\# 9 \\
(82 \%)\end{array}$ & $\begin{array}{c}\# 0 \\
(0 \%)\end{array}$ & $\begin{array}{c}\# 7 \\
(64 \%)\end{array}$ & $\begin{array}{c}\# 3 \\
(27 \%)\end{array}$ & $\begin{array}{c}\# 9 \\
(82 \%)\end{array}$ \\
\hline & & $\begin{array}{c}\text { Economic } \\
\text { Performance } \\
\# 12 \\
(75 \%)\end{array}$ & $\begin{array}{l}\text { G4-EC1 } \\
\# 11 \\
(92 \%)\end{array}$ & $\begin{array}{c}\# 9 \\
(82 \%)\end{array}$ & $\begin{array}{c}\# 11 \\
(100 \%)\end{array}$ & $\begin{array}{c}\# 0 \\
(0 \%)\end{array}$ & $\begin{array}{c}\# 11 \\
(100 \%)\end{array}$ & $\begin{array}{c}\# 3 \\
(27 \%)\end{array}$ & $\begin{array}{c}\# 11 \\
(100 \%)\end{array}$ & $\begin{array}{c}\# 6 \\
(55 \%)\end{array}$ & $\begin{array}{c}\# 11 \\
(100 \%)\end{array}$ \\
\hline
\end{tabular}

\footnotetext{
Note:

(1) The \% of incidences calculated on the sample of oil and gas companies at Stage 0.

(2) The \% of incidences calculated on the comparable companies at Stage 1.

(3) The $\%$ of incidences calculated on the companies at Stage 2.

(4) The \% of incidences calculated on the companies at Stage 3.
}

Source: Compiled by the authors on the basis of GRI Reports List and companies' sustainability reports.

Out of eight indicators, only two implemented the criteria with an average level of more than 75\%: G4-EN15 (direct GHG emissions) and G4-LA6 (occupational health and safety measures). Despite only two indicators crossing the $75 \%$ bottom line, the average level of adherence to the criteria is almost that high. On average, the implementation of the comparability criteria for the indicators is $70 \%$, with a maximum of $89 \%$ for G4-EN15 (GHG emissions, Scope 1) and a minimum of $44 \%$ for G4-EN24 (significant spills). All the criteria are implemented in 71\% of reports on average. The companies usually disclose annual (96\%) quantitative data (98\%) in generally accepted measures (95\%) with the breakdown (89\%), supported by the context over the data and/or its dynamics (93\%). The representation of the total numbers and ratios was implemented by only $45 \%$ of companies, the method of evaluation is represented in only $32 \%$ of cases, and the least popular criterion was benchmarking $(24 \%)$. The differences in the implementation of criteria are broad and can be explained by the fact that five criteria with high levels of implementation were easy to use, while the other three criteria were found by companies to be difficult. 
With regards to the implementation of the criteria, it is vital to mention that the way companies implement them varies. First of all, the quantitative data are represented in different forms: tables, texts, and infographics. Contextual comments can be represented separately from quantitative data and may vary from technical explanations to management approach descriptions. The ratios are calculated with different bases and measured differently. The benchmarks may be in the form of ratings or indices, or the company can provide statistics over its own indicators and the indicators of its peers. The breakdown of the numbers is different and does not always correspond to the GRI requirements. The method of evaluation is usually represented very generally or concerns only precise elements of the methodology.

The level of data comparability can be assumed to be close to high (70-71\%). However, the high results are applicable to only $39 \%$ of the sample companies, which diminishes the results and makes the overall comparability of oil and gas companies very low. Moreover, only two indicators have an average level of criteria implementation of more than $75 \%$. Additionally, the way of implementing the criteria varies significantly, which poses additional barriers in comparing the data. Thus, the overall comparability of the ESG data across oil and gas companies can be assumed to be low.

\section{Discussion}

The results were less than theoretically expected. Notwithstanding, it was not expected that all the material aspects treated by the companies would be the same or that all the same indicators would be provided; the industry effect was expected to be higher to allow investors to select the most ESG responsible companies in the sector.

The low level of practical results can be explained by some factors that determine the difference between companies.

According to the stakeholder and legitimacy theories, such factors explain the difference in the stakeholder environment or in the level of the need to legitimize the company's activities by the stakeholders. In this research, such factors were neutralised. Firstly, the companies from one sector were chosen to avoid the stakeholder variance between companies. Furthermore, only listed companies were taken for the analysis with the aim to choose companies with a potentially similar level of motivation for ESG legitimization. As far as the results show a low level of comparability, it can be suggested that the stakeholder and legitimacy theories are explaining the comparability issue only partially.

According to the literature review, there are other factors with a potential influence on the level of comparability [24]: (1) the characteristics of the company (size), (2) corporate governance, and (3) the characteristics of the external context (country of presence).

First of all, the size of the company influences the reporting practice, as bigger companies have higher pressure from stakeholders for ESG disclosure. In this study the companies from the sample are preferably large companies in accordance to GRI Reports List (with a headcount equal to or above 250 and a turnover of more than 50 million EUR or total assets more than 43 million). However, if we look more precisely at the size of the companies from the comparable sample, it is possible to find out that the variance coefficients for the firm size are very high: $215 \%$ for the headcount, $642 \%$ for the turnover, and $409 \%$ for the total assets. Hence, the big variance in size tells that even a comparable sample consists of heterogeneous companies. Such companies have different needs for ESG legitimization, which makes them not comparable.

The next factor, the diversity in the corporate governance systems impacts the level of comparability. The way a company manages CSR influences the way it reports on CSR. Researchers provide a variety of corporate governance characteristics that influence sustainability disclosure: board size [30], ownership structure [29], presence of audit committee [29], CEO duality [30], category of directors [31], board independence [29,30], presence of CSR committee [24,31-33], presence of CSR value in the mission and vision, and partnership with NGO [33]. The most widespread board characteristic that is proven to have an influence on sustainability disclosure is the presence of a CSR 
committee [24,31-34]. In this study, 50\% of the companies from the comparable sample have a CSR committee at the level of the Board of Directors, the other $50 \%$ of the companies have a lower level of the CSR governance. Hence, the attitude to the ESG disclosure is different even between a comparable sample of companies which leads to the low level of comparability between them.

Finally, the variety of countries of presence can make stakeholder surroundings different for the companies and lead to a different normative context for them. In this research, the initial sample of 41 companies represented 24 countries (1.7 companies per country in general) and a comparable sample of 16 companies represented 11 companies (1.5 companies per country in general). Moreover, only two countries have more than one comparable company: Thailand and Russia. Such diverse country representation allows to suggest that companies have different stakeholders, who, in turn, create different normative contexts for the companies. Thus, the companies from different countries are becoming less comparable.

As far as the absence of intra-industry comparability is a proven fact and the roots of the problem are determined, theoretical and practical actions can be suggested for solving this problem.

From a theoretical point of view, the lack of comparability might justify the controversial impact of ESG results on company performance. Thus, the scientific works should be more concentrated on the quality characteristics of sustainability disclosure rather than on ESG performance. Such an approach will help to boost the comparability among companies and make the scientific results less ambiguous. However, this approach will diminish the value of the data from the report due to the lack of data analysis. Thus, the practical steps are needed to eliminate the roots of the problem.

Nonetheless, there is already an ongoing work for increasing the level of comparability in practice; there is still a gap to bridge. The GRI Standards are created and promoted with the aim to enhance the global comparability and quality of information on ESG impacts [27]. Nevertheless, the implementation of the GRI Standards is still heterogeneous due the abovementioned fundamental factors: governance structure, variance in size, and country difference. The impact of these factors can be reduced by consulting the companies over the place of the CSR body in the governance structure, by including little companies into the market regulation rules concerning ESG reporting, and by unifying the market norms between countries. The last solution is already in progress due to the Sustainable Stock Exchanges Initiative that is a peer-to-peer learning platform for exploring how exchanges, in collaboration with investors, regulators, and companies, can enhance corporate transparency on a global level [12]. As long as the most interested parties in the ESG comparability are investors, these solutions are suggested for the investment community: asset owners and investors, NGO, stock exchanges, rating agencies.

\section{Conclusions}

ESG data are used by many stakeholders, and the demand for ESG information is growing. The investment community is one of the most interested and influential parties of all stakeholder groups because there is a growing number of responsible investors who redirect their funds to socially and ecologically responsible investments. Despite this, the use of ESG data by investors is still difficult due to the quality of the data, and the impact of ESG disclosure on firm performance is still controversial.

In this paper, we investigated the quality of the ESG data for oil and gas listed companies, focusing our attention on their level of comparability. The comparability of ESG data is crucial for the profitable use of the information by investors.

Using a multiple stages model, our findings show that there is comparability for a very narrow sample of companies and indicators (Table 7). Out of all 41 oil and gas companies with GRI reports, only $39 \%$ were suggested as comparable at the first stage of our analysis where the correlation with the GRI was checked. Moreover, out of all 51 GRI aspects described in the reports, only four appear in more than $75 \%$ of the companies' reports. Among these most widespread aspects, there are only 8 most material indicators out of the 23 possible GRI indicators (35\%). Looking at the last stage of 
analysis, only two indicators were implemented in accordance with the eight comparability criteria in more than $75 \%$ of cases.

Table 7. The overall results.

\begin{tabular}{|c|c|c|c|}
\hline $\begin{array}{c}\text { Stage of } \\
\text { Comparability }\end{array}$ & Output & Result in Total Numbers & $\begin{array}{l}\text { Result in } \\
\text { Percentage }\end{array}$ \\
\hline Stage 0 & $\begin{array}{c}\text { Sample } 0 \\
\text { Oil and gas sustainability reports }\end{array}$ & 41 reports out of 68 & $60.2 \%$ \\
\hline Stage 1 & $\begin{array}{c}\text { Subsample } 1 \\
\text { Comparable reports }\end{array}$ & 16 reports out of 41 & $39.0 \%$ \\
\hline Stage 2 & $\begin{array}{c}\text { Subsample } 2 \\
\text { Selection of most reported } \\
\text { material aspects }\end{array}$ & $\begin{array}{l}4 \text { aspects out of } 51 \text { appear in more than } 75 \% \\
\text { of companies from subsample } 1\end{array}$ & $7.8 \%$ \\
\hline Stage 3 & $\begin{array}{c}\text { Subsample 3 } \\
\text { Selection of most reported indicators }\end{array}$ & $\begin{array}{l}8 \text { indicators out of } 23 \text { appear in more } \\
\text { than } 75 \% \text { of companies from subsample } 1\end{array}$ & $34.8 \%$ \\
\hline Stage 4 & $\begin{array}{l}\text { Qualitative characteristics of } \\
\text { indicators for comparability }\end{array}$ & $\begin{array}{c}2 \text { indicators out of } 8 \text { implemented more } \\
\text { than } 75 \% \text { of qualitative characteristics } \\
\text { of comparability }\end{array}$ & $25.0 \%$ \\
\hline
\end{tabular}

Source: Compiled by the authors on the basis of GRI Reports List and companies' sustainability reports.

Our findings reveal that, despite the availability of a large amount of ESG data and the efforts of organizations to increase the quality of these data, a relevant problem of comparability still exists. This mainly depends on the absence of mandatory regulatory constraints in terms of social reporting. Considering this context, companies prefer to meet the expectations of their stakeholders and to legitimize themselves in the communities in which they operate rather than to comply with nonbinding rules in terms of social reporting.

Therefore, the lack of comparability might justify the controversial impact of ESG disclosure on company performance and constitutes a big limit in the use of this information on capital markets. If the reports cannot be compared, rating and ranking agencies try to help investors find more general comparable ESG features. In this case, the characteristics of the report or the company itself are analyzed rather than the particular ESG data about a company's environmental or social influence. Such an approach helps to boost the comparability but diminishes the value of the data in the report due to a lack of data analysis.

Our findings are in line with the proven statement of the low quality of ESG data, but they concentrate only on the one quality characteristic: the comparability of the data. Such specification allows us to be more precise and to estimate the ability of investors to use the ESG data. Moreover, this research, unlike previous works, is undertaken in one industry: the oil and gas sector. This specificity helps to check the influence of the industry and the listing at the stock exchange on the comparability of ESG data and to estimate whether these factors are strong enough to make the data comparable.

This paper provides a base for future research in the sphere of data comparability and allows for moving forward in understanding the phenomenon. Some suggestions are provided in this study for the theoretical and practical development of this sphere. As long as the level of ESG data comparability is low, the scientific works should be more concentrated on the quality characteristics of sustainability disclosure rather than on ESG performance. Such an approach will help to boost the comparability among companies and make scientific results less ambiguous. In order to eliminate the problem of ESG data comparability in practice, it is proposed to minimize the influence of the following factors: the difference in the level of CSR governance body in corporate structure, the specificities of country ESG disclosure norms, and the low attention to small and medium companies. The ideas for development are suggested for the investment community as long as it is the most interested party in the ESG comparability. 
As far as the limits of the analysis are concerned, there can be mentioned some. Firstly, this paper considers comparability in a static manner. However, dynamic research can be done to check whether the results are stable over time and whether a trend of increase in comparability exists in response to increased responsible investment. Moreover, broadening the industry coverage by research may help in understanding the overall level of comparability across all industries. In closing, an additional future stream of research can be to examine the relationship between the ESG data comparability and companies' financial market performance to estimate the value relevance of comparability.

Author Contributions: Although this paper is the result of the joint work of the authors, the individual contributions can be attributed to A.C. for Sections 2 and 3.2; to E.K. for Section 3.1, Section 4, and Section 5; and to S.T. for Sections 1 and 6.

Funding: This research received no external funding.

Acknowledgments: One of the authors (E.K.) is attending the program I.Ph.D.@UNIPG. Global Reporting Initiative (GRI) provided the Reports List (retrieved in November 2018) of oil and gas listed companies available on the GRI Database and their collected metadata for this research. Non-commercial partnership Agency "Da-Strategy" contributed to the data collection for this research.

Conflicts of Interest: The authors declare no conflicts of interest.

\section{Appendix A}

Table A1. Material aspects disclosed by the oil and gas companies in the sample.

\begin{tabular}{|c|c|c|c|c|}
\hline № & Aspect from GRI and GRI Oil and Gas Supplement & $\begin{array}{l}\text { Number of } \\
\text { Companies }\end{array}$ & $\begin{array}{c}\% \text { of } \\
\text { Subsample } 1\end{array}$ & $\begin{array}{c}\% \text { of } \\
\text { Sample } 0\end{array}$ \\
\hline 1. & Emissions & 14 & $88 \%$ & $34 \%$ \\
\hline 2. & Occupational Health and Safety & 14 & $88 \%$ & $34 \%$ \\
\hline 3. & Effluents and Waste & 13 & $81 \%$ & $32 \%$ \\
\hline 4. & Economic Performance & 12 & $75 \%$ & $29 \%$ \\
\hline 5. & Energy & 10 & $63 \%$ & $24 \%$ \\
\hline 6. & Water & 10 & $63 \%$ & $24 \%$ \\
\hline 7. & Employment & 10 & $63 \%$ & $24 \%$ \\
\hline 8. & Training and Education & 10 & $63 \%$ & $24 \%$ \\
\hline 9. & Anticorruption & 10 & $63 \%$ & $24 \%$ \\
\hline 10. & Local Communities & 9 & $56 \%$ & $22 \%$ \\
\hline 11. & Compliance (with Environmental Law) & 8 & $50 \%$ & $20 \%$ \\
\hline 12. & Emergency Preparedness (Oil and Gas Supplement) & 8 & $50 \%$ & $20 \%$ \\
\hline 13. & Indirect Economic Impacts & 7 & $44 \%$ & $17 \%$ \\
\hline 14. & Procurement Practices & 7 & $44 \%$ & $17 \%$ \\
\hline 15. & Compliance (with Laws in Social Sphere) & 7 & $44 \%$ & $17 \%$ \\
\hline 16. & Asset Integrity and Process Safety (Oil and Gas Supplement) & 7 & $44 \%$ & $17 \%$ \\
\hline 17. & Biodiversity (Ecosystem Services, Including Biodiversity) & 6 & $38 \%$ & $15 \%$ \\
\hline 18. & Supplier Environmental Assessment & 6 & $38 \%$ & $15 \%$ \\
\hline 19. & Diversity and Equal Opportunity & 6 & $38 \%$ & $15 \%$ \\
\hline 20. & Labor Practices Grievance Mechanisms & 6 & $38 \%$ & $15 \%$ \\
\hline 21. & Product and Service Labeling & 6 & $38 \%$ & $15 \%$ \\
\hline 22. & Overall (Environmental) & 5 & $31 \%$ & $12 \%$ \\
\hline 23. & Supplier Assessment for Labor Practices & 5 & $31 \%$ & $12 \%$ \\
\hline 24. & Customer Health and Safety & 5 & $31 \%$ & $12 \%$ \\
\hline
\end{tabular}


Table A1. Cont.

\begin{tabular}{|c|c|c|c|c|}
\hline № & Aspect from GRI and GRI Oil and Gas Supplement & $\begin{array}{l}\text { Number of } \\
\text { Companies }\end{array}$ & $\begin{array}{c}\% \text { of } \\
\text { Subsample } 1\end{array}$ & $\begin{array}{c}\% \text { of } \\
\text { Sample } 0\end{array}$ \\
\hline 25. & Reserves (Oil and Gas Supplement) & 4 & $25 \%$ & $10 \%$ \\
\hline 26. & Indigenous Rights & 4 & $25 \%$ & $10 \%$ \\
\hline 27. & Supplier Human Rights Assessment & 4 & $25 \%$ & $10 \%$ \\
\hline 28. & Compliance (with Laws in the Sphere of Product Safety) & 4 & $25 \%$ & $10 \%$ \\
\hline 29. & Market Presence & 3 & $19 \%$ & $7 \%$ \\
\hline 30. & Materials & 3 & $19 \%$ & $7 \%$ \\
\hline 31. & Products and Services & 3 & $19 \%$ & $7 \%$ \\
\hline 32. & Labor/Management Relations & 3 & $19 \%$ & $7 \%$ \\
\hline 33. & Equal Remuneration for Women and Men & 3 & $19 \%$ & $7 \%$ \\
\hline 34. & Freedom of Association and Collective Bargaining & 3 & $19 \%$ & $7 \%$ \\
\hline 35. & Human Rights Grievance Mechanisms & 3 & $19 \%$ & $7 \%$ \\
\hline 36. & Public Policy & 3 & $19 \%$ & $7 \%$ \\
\hline 37. & Supplier Assessment for Impacts on Society & 3 & $19 \%$ & $7 \%$ \\
\hline 38. & Grievance Mechanisms for Impacts on Society & 3 & $19 \%$ & $7 \%$ \\
\hline 39. & Marketing Communications & 3 & $19 \%$ & $7 \%$ \\
\hline 40. & Customer Privacy & 3 & $19 \%$ & $7 \%$ \\
\hline 41. & Transport & 2 & $13 \%$ & $5 \%$ \\
\hline 42. & Environmental Grievance Mechanisms & 2 & $13 \%$ & $5 \%$ \\
\hline 43. & Nondiscrimination & 2 & $13 \%$ & $5 \%$ \\
\hline 44. & Child Labor & 2 & $13 \%$ & $5 \%$ \\
\hline 45. & Fossil Fuel Substitutes (Oil and Gas Supplement) & 2 & $13 \%$ & $5 \%$ \\
\hline 46. & Forced or Compulsory Labor & 1 & $6 \%$ & $2 \%$ \\
\hline 47. & Security Practices & 1 & $6 \%$ & $2 \%$ \\
\hline 48. & Assessment (of Human Rights Practices) & 1 & $6 \%$ & $2 \%$ \\
\hline 49. & Anticompetitive Behavior & 1 & $6 \%$ & $2 \%$ \\
\hline 50. & Investment (in Human Rights) & 0 & $0 \%$ & $0 \%$ \\
\hline 51. & Involuntary Resettlement (Oil and Gas Supplement) & 0 & $0 \%$ & $0 \%$ \\
\hline
\end{tabular}

\section{Appendix B}

Table A2. Indicators disclosed for the most reported material aspects.

\begin{tabular}{ccccc}
\hline \multirow{2}{*}{$\begin{array}{c}\text { Material } \\
\text { Aspect }\end{array}$} & $\begin{array}{c}\text { Number of } \\
\text { Companies }\end{array}$ & Indicators & $\begin{array}{c}\text { Number of } \\
\text { Companies }\end{array}$ & \% \\
\hline & & G4-EN15: Direct greenhouse gas (GHG) emissions (Scope 1) & 12 & $86 \%$ \\
\cline { 3 - 5 } & & G4-EN16: Energy indirect GHG emissions (Scope 2) & 11 & $79 \%$ \\
\cline { 3 - 5 } Emissions & \multirow{2}{*}{14} & G4-EN17: Other indirect GHG emissions (Scope 3) & 4 & $29 \%$ \\
\cline { 3 - 5 } & & G4-EN18: GHG emissions intensity & 10 & $71 \%$ \\
\cline { 3 - 5 } & & G4-EN19: Reduction of GHG emissions & 6 & $43 \%$ \\
\cline { 3 - 5 } & & EN-21: NOX, SOX, and other significant air emissions & 12 & $80 \%$ \\
\hline
\end{tabular}


Table A2. Cont.

\begin{tabular}{|c|c|c|c|c|}
\hline $\begin{array}{c}\text { Material } \\
\text { Aspect }\end{array}$ & $\begin{array}{l}\text { Number of } \\
\text { Companies }\end{array}$ & Indicators & $\begin{array}{l}\text { Number of } \\
\text { Companies }\end{array}$ & $\%$ \\
\hline \multirow{4}{*}{$\begin{array}{l}\text { Occupational } \\
\text { Health } \\
\text { and Safety }\end{array}$} & \multirow{4}{*}{14} & $\begin{array}{c}\text { G4-LA5: Percentage of total workforce represented in formal } \\
\text { joint management-worker health and safety committees } \\
\text { that help monitor and advise on occupational health } \\
\text { and safety programs }\end{array}$ & 9 & $64 \%$ \\
\hline & & $\begin{array}{l}\text { G4-LA6: Types and rates of injury, occupational diseases, lost } \\
\text { days, and absenteeism, and total number of work-related } \\
\text { fatalities by region and gender }\end{array}$ & 14 & $100 \%$ \\
\hline & & $\begin{array}{l}\text { G4-LA7: Workers with high incidence or high risk of disease } \\
\text { related to their occupation }\end{array}$ & 8 & $57 \%$ \\
\hline & & $\begin{array}{l}\text { G4-LA8: Health and safety topics covered in formal } \\
\text { agreements with trade unions }\end{array}$ & 8 & $57 \%$ \\
\hline \multirow{8}{*}{$\begin{array}{l}\text { Effluents } \\
\text { and Waste }\end{array}$} & \multirow{8}{*}{13} & G4-EN22: Total water discharge by quality and destination & 11 & $85 \%$ \\
\hline & & G4-EN23: Total weight of waste by type and disposal method & 11 & $85 \%$ \\
\hline & & G4-EN24: Total number and volume of significant spills & 11 & $85 \%$ \\
\hline & & $\begin{array}{l}\text { G4-EN25: Weight of transported, imported, exported, } \\
\text { or treated waste deemed hazardous under the terms of } \\
\text { the Basel Convention } 2\end{array}$ & 7 & $54 \%$ \\
\hline & & $\begin{array}{l}\text { G4-EN26: Identity, size, protected status, and biodiversity } \\
\text { value of water bodies and related habitats significantly } \\
\text { affected by the organization's discharge of water and runoff }\end{array}$ & 5 & $38 \%$ \\
\hline & & OG5: Volume and disposal of formed or produced water & 6 & $46 \%$ \\
\hline & & OG6: Volume of flared and vented hydrocarbon & 7 & $54 \%$ \\
\hline & & $\begin{array}{l}\text { OG7: Amount of drilling waste (drill mud and cuttings) } \\
\text { and strategies for treatment and disposal }\end{array}$ & 6 & $46 \%$ \\
\hline \multirow{4}{*}{$\begin{array}{l}\text { Economic } \\
\text { Performance }\end{array}$} & \multirow{4}{*}{12} & G4-EC1: Direct economic value generated and distributed & 11 & $100 \%$ \\
\hline & & $\begin{array}{l}\text { G4-EC2: Financial implications and other risks } \\
\text { and opportunities for the organization's activities due to } \\
\text { climate change }\end{array}$ & 5 & $45 \%$ \\
\hline & & $\begin{array}{c}\text { G4-EC3: Coverage of the organization's defined benefit } \\
\text { plan obligations }\end{array}$ & 5 & $45 \%$ \\
\hline & & G4-EC4: Financial assistance received from government & 7 & $64 \%$ \\
\hline
\end{tabular}

\section{References}

1. Tang, Z.; Hull, C.E.; Rothenberg, S. How corporate social responsibility engagement strategy moderates the CSR-financial performance relationship. J. Manag. Stud. 2012, 49, 1274-1303. [CrossRef]

2. Friede, G.; Busch, T.; Bassen, A. ESG and financial performance: Aggregated evidence from more than 2000 empirical studies. J. Sustain. Finance Invest. 2015, 5, 210-233. [CrossRef]

3. Griffin, J.J.; Mahon, J.F. The corporate social performance and corporate financial performance debate: Twenty-Five years of incomparable research. Bus. Soc. 1997, 36, 5-31. [CrossRef]

4. Riley, R.A.; Pearson, T.A.; Trompeter, G. The value relevance of non-financial performance variables and accounting information: The case of the airline industry. J. Account. Public Policy 2003, 22, 231-254. [CrossRef]

5. Margolis, J.D.; Elfenbein, H.A.; Walsh, J.P. Does it pay to be good? A meta-analysis and redirection of research on the relationship between corporate social and financial performance. MIT Sloan Manag. Rev. 2007. [CrossRef]

6. US SIF \& US SIF Foundation. The Impact of Sustainable and Responsible Investment. Available online: https:/ / www.ussif.org/files/Publications/USSIF_ImpactofSRI_FINAL.pdf (accessed on 16 February 2019).

7. PRI Institute Principles for Responsible Investment. Available online: https://www.unpri.org/pri/whatare-the-principles-for-responsible-investment (accessed on 18 February 2019). 
8. Amaeshi, K.; Grayson, D. The Challenges of Mainstreaming Environmental, Social and Governance (ESG) issues in Investment Decisions. A Mini-survey of Practitioners' Reports. Available online: http:/ / citeseerx. ist.psu.edu/viewdoc/download?doi=10.1.1.466.1773\&rep=rep1\&type=pdf (accessed on 16 February 2019).

9. CFA Institute. Environmental, Social and Governance (ESG) Survey. Available online: https://www. cfainstitute.org/-/media/documents/survey/esg-survey-report-2017.ashx (accessed on 16 February 2019).

10. Amel-Zadeh, A.; Serafeim, G. Why and how investors use ESG information: Evidence from a global survey. Financial Analysts J., Forthcom. 2017, 74. [CrossRef]

11. Directive 2014/95/EU of the European Parliament and of the Council of 22 October 2014. Amending Directive 2013/34/EU as Regards Disclosure of Non-financial and Diversity Information by Certain Large Undertakings and Groups. Available online: https://eur-lex.europa.eu/legal-content/EN/TXT/PDF/?uri=CELEX: 32014L0095\&from=FI (accessed on 16 February 2019).

12. Miller, A.; Grabski, T. 2018 Report on Progress: A Paper Prepared for the Sustainable Stock Exchanges 2018 Global Dialogue. Available online: http://www.sseinitiative.org/wp-content/uploads/2018/10/SSE_On_ Progress_Report_FINAL.pdf (accessed on 16 February 2019).

13. Bostwick, S.; Chesebrough, D.; Feller, E.; Miller, A. Model Guidance on Reporting ESG Information to Investors. Available online: http://www.sseinitiative.org/wp-content/uploads/2015/09/SSE-ModelGuidance-on-Reporting-ESG.pdf (accessed on 16 February 2019).

14. Climate Disclosure Standards Board. Insights from the Reporting Exchange: ESG Reporting Trends. Available online: https://www.cdsb.net/sites/default/files/cdsb_report_1_esg.pdf (accessed on 16 February 2019).

15. Ioannou, I.; Serafeim, G. The Consequences of Mandatory Corporate Sustainability Reporting. Available online: https:/ / papers.ssrn.com/sol3/papers.cfm?abstract_id=1799589 (accessed on 16 February 2019).

16. Zeff, S.A. Some obstacles to global financial reporting comparability and convergence at a high level of quality. Br. Account. Rev. 2007, 39, 290-302. [CrossRef]

17. Krisement, V.M. An approach for measuring the degree of comparability of financial accounting information. Eur. Account. Rev. 1997, 6, 465-485. [CrossRef]

18. Habek, P.; Habek, P. CSR Reporting Practices in Visegrad Group Countries and the Quality of Disclosure. Sustainability 2017, 9, 1-18. [CrossRef]

19. Habek, P.; Wolniak, R. Assessing the quality of corporate social responsibility reports: The case of reporting practices in selected European Union member states. Qual. Quant. 2016, 50, 399-420. [CrossRef]

20. Leitoniene, S.; Sapkauskiene, A. Quality of corporate social responsibility information. Procedia Soc. Behav. Sci. 2015, 213, 334-339. [CrossRef]

21. de la Cuesta, M.; Valor, C. Evaluation of the environmental, social and governance information disclosed by Spanish listed companies. Soc. Responsib. J. 2013, 9, 220-240. [CrossRef]

22. Cascino, S.; Gassen, J. What drives the comparability effect of mandatory IFRS adoption? Rev. Account. Stud. 2015, 20, 242-282. [CrossRef]

23. Franco, G.D.; Kothari, S.P.; Verdi, R.S. The benefits of financial statement comparability. J. Account. Res. 2011, 49, 895-931. [CrossRef]

24. Adams, C.A. Internal organisational factors influencing corporate social and ethical reporting: Beyond current theorising. Acc. Audit. Account. J. 2002, 15, 223-250. [CrossRef]

25. Dang, C.; (Frank) Li, Z.; Yang, C. Measuring firm size in empirical corporate finance. J. Bank. Finance 2018, 86, 159-176. [CrossRef]

26. Gallo, P.J.; Christensen, L.J. Firm size matters: An empirical investigation of organizational size and ownership on sustainability-related behaviors. Bus. Soc. 2011, 50, 315-349. [CrossRef]

27. Eccles, R.G.; Krzus, M.P.; Rogers, J.; Serafeim, G. The need for sector-specific materiality and sustainability reporting standards. J. Appl. Corp. Finance 2012, 24, 65-71. [CrossRef]

28. Deegan, C.; Gordon, B. A study of the environmental disclosure practices of Australian corporations. Account. Bus. Res. 1996, 26, 187-199. [CrossRef]

29. Khan, A.; Muttakin, M.B.; Siddiqui, J. Corporate governance and corporate social responsibility disclosures: Evidence from an emerging economy. J. Bus. Ethics 2013, 114, 207-223. [CrossRef]

30. Jizi, M.I.; Salama, A.; Dixon, R.; Stratling, R. Corporate governance and corporate social responsibility disclosure: Evidence from the US banking sector. J. Bus. Ethics 2014, 125, 601-615. [CrossRef]

31. Michelon, G.; Parbonetti, A. The effect of corporate governance on sustainability disclosure. J. Manag. Gov. 2012, 16, 477-509. [CrossRef] 
32. Peters, G.F.; Romi, A.M. The Association between Sustainability Governance Characteristics and the Assurance of Corporate Sustainability Reports. Available online: https:/ / aaapubs.org/doi/10.2308/ajpt-50849 (accessed on 20 January 2019).

33. Amran, A.; Lee, S.P.; Devi, S.S. The influence of governance structure and strategic corporate social responsibility toward sustainability reporting quality. Bus. Strat. Environ. 2014, 23, 217-235. [CrossRef]

34. Cowen, S.S.; Ferreri, L.B.; Parker, L.D. The impact of corporate characteristics on social responsibility disclosure: A typology and frequency-based analysis. Account. Organ. Soc. 1987, 12, 111-122. [CrossRef]

35. Li, F.; Li, T.; Minor, D. CEO power, corporate social responsibility, and firm value: A test of agency theory. Int. J. Manag. Finance 2016, 12, 611-628. [CrossRef]

36. Escobar, L.F.; Vredenburg, H. Multinational oil companies and the adoption of sustainable development: A resource-based and institutional theory interpretation of adoption heterogeneity. J. Bus. Ethics 2011, 98, 39-65. [CrossRef]

37. Baldini, M.; Maso, L.D.; Liberatore, G.; Mazzi, F.; Terzani, S. Role of country- and firm-level determinants in environmental, social, and governance disclosure. J. Bus. Ethics 2018, 150, 79-98. [CrossRef]

38. Mintzberg, H. Power In and Around Organizations 1983, Englewood Cliffs, N.J.: Prentice-Hall. Organ. Stud. 1984, 5, 377-378.

39. Deegan, C.; Shelly, M. Corporate social responsibilities: Alternative perspectives about the need to legislate. J. Bus. Ethics 2014, 121, 499-526. [CrossRef]

40. Dowling, J.; Pfeffer, J. Organizational legitimacy: Social values and organizational behavior. Pac. Sociol. Rev. 1975, 18, 122-136. [CrossRef]

41. Singh, J.V.; House, R.J.; Tucker, D.J. Organizational change and organizational mortality. Adm. Sci. Q. 1986, 31, 587-611. [CrossRef]

42. Johnson, H.M. Questioning organizational legitimacy: The case of U.S. expatriates. J. Bus. Ethics 2003, 47, 269-293. [CrossRef]

43. Deegan, C. Introduction: The legitimising effect of social and environmental disclosures-a theoretical foundation. Acc. Audit. Account. J. 2002, 15, 282-311. [CrossRef]

44. Tregidga, H.; Milne, M.; Kearins, K. Organisational Legitimacy and Social and Environmental Reporting Research: The Potential of Discourse Analysis. Available online: https:/ /pdfs.semanticscholar.org/3329/ ca9c30201b4a0a21a97f50a9c9b4016b5ed6.pdf (accessed on 18 February 2019).

45. Ashforth, B.E.; Gibbs, B.W. The double-edge of organizational legitimation. Organ. Sci. 1990, 1, $177-194$. [CrossRef]

46. Patten, D.M. The accuracy of financial report projections of future environmental capital expenditures: A research note. Account. Organ. Soc. 2005, 30, 457-468. [CrossRef]

47. Lindblom, C.K. The implications of Organizational Legitimacy for Corporate Social Performance and Disclosure. Available online: https:/ / ci.nii.ac.jp/naid/10025885553/ (accessed on 18 February 2019).

48. Freeman, R. Strategic Management: A Stakeholder Approach; Cambridge University Press: Cambridge, UK, 1984; ISBN 978-0-521-15174-0.

49. Freeman, R.E.; McVea, J. A Stakeholder Approach to Strategic Management; Social Science Research Network: Rochester, NY, USA, 2001.

50. Freeman, R.E. The Stakeholder Approach Revisited. Available online: https://www.ssoar.info/ssoar/ bitstream/handle/document/34707/ssoar-zfwu-2004-3-freeman-The_stakeholder_approach_revisited. pdf?sequence=1 (accessed on 16 February 2019).

51. Lokuwaduge, C.S.D.S.; Heenetigala, K. Integrating environmental, social and governance (ESG) disclosure for a sustainable development: An Australian study. Bus. Strat. Environ. 2017, 26, 438-450. [CrossRef]

52. Trueblood, R.M. Accounting principles: The board and its problems. J. Account. Res. 1966, 4, $183-191$. [CrossRef]

53. Wu, J.S.; Zhang, I. Accounting Integration and Comparability: Evidence from Relative Performance Evaluation Around IFRS Adoption; Social Science Research Network: Rochester, NY, USA, 2010.

54. Lobo, G.J.; Neel, M.J.; Rhodes, A. Accounting Comparability and Relative Performance Evaluation in CEO Compensation; Social Science Research Network: Rochester, NY, USA, 2018.

55. Vukić, N.M.; Vuković, R.; Calace, D. Non-financial reporting as a new trend in sustainability accounting. J. Account. Manag. 2017, 7, 13-26. 
56. GRI. GRI Standards; GRI Secretariat. Available online: https://www.globalreporting.org/standards/gristandards-download-center/ (accessed on 18 February 2019).

57. The International Integrated Reporting Council (IIRC). The International Integrated Reporting Framework. Available online: http:/ /integratedreporting.org/wp-content/uploads/2015/03/13-12-08THE-INTERNATIONAL-IR-FRAMEWORK-2-1.pdf (accessed on 18 February 2019).

58. International Accounting Standards Board. Conceptual Framework for Financial Reporting; IFRS Foundation Publ. Department: London, UK, 2010; ISBN 978-1-907026-69-0.

59. Financial Accounting Standards Board. Conceptual Framework for Financial Reporting. 2018. Available online: https: / / www.fasb.org/jsp/FASB/Document_C/DocumentPage?cid=1176171111398\&acceptedDisclaimer=true (accessed on 18 February 2019).

60. Climate Disclosure Standards Board (CDSB). CDSB Framework for Reporting Environmental Information, Natural Capital and Associated Business Impacts. 2018. Available online: https:/ /www.cdsb.net/sites / default/files/cdsb_framework_2.1.pdf (accessed on 18 February 2019).

61. Sustainability Accounting Standards Board. SASB Conceptual Framework. 2017. Available online: https://www. sasb.org/wp-content/uploads/2017/02/SASB-Conceptual-Framework.pdf (accessed on 18 February 2019).

62. Task Force on Climate-related Financial Disclosures. Recommendations of the Task Force on Climate-related Financial Disclosures. 2017. Available online: https:/ /www.fsb-tcfd.org/wp-content/uploads/2017/06/ FINAL-TCFD-Report-062817.pdf (accessed on 18 February 2019).

63. G4 Sector Disclosures. Available online: https://www.globalreporting.org/information/sector-guidance/ sectorguidanceG4/Pages / default.aspx (accessed on 9 December 2018).

64. Yin, R.K. The Case Study Anthology; SAGE: Thousand Oaks, CA, USA, 2004; ISBN 978-0-7619-2926-0.

65. Bonsón, E.; Bednárová, M. CSR reporting practices of Eurozone companies. Rev. Contab. 2015, 18, 182-193. [CrossRef]

66. SDD-GRI Database. Available online: http:/ / database.globalreporting.org/ (accessed on 29 November 2018).

67. Maier, S. Valuing ESG Issues-A Survey of Investors. Available online: https://www.upj.de/fileadmin/ user_upload/MAIN-dateien/Infopool/Forschung/eiris_investor_2007.pdf (accessed on 16 February 2019).

68. Jianu, I.; Jianu, I. The share price and investment: Current footprints for future oil and gas industry performance. Energies 2018, 11, 448. [CrossRef]

69. World Bank National Accounts Data, and OECD National Accounts Data Files. Available online: https: / / data.worldbank.org/ (accessed on 30 November 2018).

70. El Hedi Arouri, M.; Jouini, J.; Nguyen, D.K. Volatility spillovers between oil prices and stock sector returns: Implications for portfolio management. J. Int. Money Finance 2011, 30, 1387-1405. [CrossRef]

71. Carini, C.; Rocca, L.; Veneziani, M.; Teodori, C. Ex-Ante impact assessment of sustainability information-the directive 2014/95. Sustainability 2018, 10, 560. [CrossRef]

72. Park, A.; Ravenel, C. Integrating sustainability into capital markets: Bloomberg LP and ESG's quantitative legitimacy. J. Appl. Corp. Finance 2013, 25, 62-67.

73. GRI Annual Report 2016-2017. GRI, 2018. Available online: https://www.globalreporting.org/ resourcelibrary/GRI\%20Annual\%20Report\%202016-2017.pdf (accessed on 18 February 2019).

74. Romolini, A.; Fissi, S.; Gori, E. Scoring CSR reporting in listed companies-evidence from Italian best practices. Corp. Soc. Responsib. Environ. Manag. 2014, 21, 65-81. [CrossRef]

75. Slowak, A.P.; Taticchi, P. Technology, policy and management for carbon reduction: A critical and global review with insights on the role played by the Chinese Academy. J. Clean. Prod. 2015, 103, 601-619. [CrossRef]

(C) 2019 by the authors. Licensee MDPI, Basel, Switzerland. This article is an open access article distributed under the terms and conditions of the Creative Commons Attribution (CC BY) license (http://creativecommons.org/licenses/by/4.0/). 